\title{
Additions to the Piophilidae (Diptera) fauna from Portugal, with new records
}

\author{
C. Prado e Castro $^{1,2^{*}} \&$ M. D. García ${ }^{3}$
}

The Piophilidae are small to medium-sized flies (3-8 mm), brown to black in colour (Ozerov, 2000). The adults visit decaying carcasses, bones, garbage, filth, excrements, sewage, and other proteinaceous animal and vegetable matter (McAlpine, 1977). Larvae of Piophilidae breed mainly on decomposing fungi and plant matter or carrion of vertebrate animals and high-protein resources. At least one species, Neottiophilum praeustum (Meigen, 1826), lives in birds nests, where they act as ectoparasites, feeding on nestlings' blood (McAlpine, 1977; Ozerov, 2000). Several species prefer a human environment, where food supply and living conditions are favourable (McAlpine, 1977). Piophilidae larvae are often recovered from carcasses, including human corpses in advanced stages of decay, as the body begins to dry, even though adults may be found in corpses only 3 to 4 days after death (Smith, 1986).

The habit of jumping and skipping is well documented for Piophila casei (Linnaeus, 1758), but it is probable that the larvae of many other species (possibly all) in the family possess the same capacities (McAlpine, 1977; Ozerov, 2000). The skipping ability is most pronounced during migration, even if undisturbed, but it is also a useful escape mechanism in times of danger (Simmons, 1927).

Piophilidae are found in all continents, but the family is richest in the temperate portion of the Northern Hemisphere, many species having Holarctic distributions. A few species developed synanthropic tendencies - e.g. Piophila casei, Stearibia nigriceps (Meigen, 1826) and Prochyliza nigrimana (Meigen, 1826) - and have accompanied man to many parts of the world (McAlpine, 1977).

Presently, more than 70 species of 24 genera are included in Piophilidae (Ozerov, 2000), of which some 16 genera and about 30 species are present in Europe (Oosterbroek, 2006). In the Iberian Peninsula, 3 Piophilidae species are recorded for Portugal (1 in portuguese mainland, 2 in Azores and Madeira) and 9 for Spain (Carles-Tolrá \& Báez, 2002; Gómez-Gómez et al., 2008).

The aim of this paper is to report 4 Piophilidae species new for continental Portugal, within a total of 5 that were collected from animal carcasses. The biology and distribution of the species is commented and data on seasonality of species is presented, in order to contribute to a better knowledge of this family, in a country where Diptera are still poorly known.

Fieldwork was conducted in the city of Coimbra, at Jardim Botânico da Universidade de Coimbra (UTM coordinate 29TNE45 - Coimbra, Beira Litoral; altitude: $55 \mathrm{~m}$ ), from May to September 2004 and in Lisbon, at Instituto Superior de Agronomia (UTM coordinate 29SMC88 - Lisbon, Estremadura; altitude: $80 \mathrm{~m}$ ), from October 2006 to August 2007. Both sites are small patchy woodland parks inside the urban perimeter. The study site, in Coimbra, had vegetation mainly composed of Ailanthus altissima (Mill.) Swingle, Laurus nobilis L., Celtis australis L., Olea europaea L. and Eucalyptus L'Hér. The site was in a clearing with direct sunlight almost all day. In Lisbon, the habitat had Ailanthus altissima (Mill.) Swingle, Fraxinus

\footnotetext{
Centro de Biologia Ambiental, Departamento de Biologia Animal, Faculdade de Ciências da Universidade de Lisboa, Ed. C2, Campo Grande, 1749-016 Lisboa, Portugal.

Centro de Ciências Forenses, Instituto Nacional de Medicina Legal, Coimbra, Portugal.

Corresponding author. Email: cbcastro@fc.ul.pt

Área de Zoología, Facultad de Biología, Universidad de Murcia, 30100 Murcia, España.
} 
angustifolia Vahl and Ulmus minor Miller as the predominant species. The site had less solar exposure.

The experiments consisted of leaving a dead animal (piglet) in the field and collecting the insects that colonized the body, both adult and immature forms, during periodical visits. This was made daily for the first three to four weeks and afterwards on alternate days. A version of a Schoenly trap designed to collect sarcosaprophagous arthropods (Prado e Castro et al., 2009) was used, with piglets as bait. In the 2004 experiment, a $5 \mathrm{~kg}$ piglet was used for a period of 4 months (Prado e Castro, 2005). In 2006-2007, four different experiments of 10 weeks were performed, with four different piglets, in order to cover all seasons of the year. A $40 \%$ ethylene glycol solution with formalin and detergent was used in the trap as killing and temporary preservative agent for the arthropods, after which they were placed in $80 \%$ ethanol. The adult Piophilidae collected have been identified based on McAlpine (1977).

The classification used is according to McAlpine (1977). All species belong to Piophilini tribe and Piophilina subtribe.

\section{Liopiophila varipes (Meigen, 1830)}

The genus Liopiophila Duda, 1924 has a single, common species, L. varipes that occurs in the Holarctic region (McAlpine, 1977; Zuska, 1984). It is the first record of the species for Portugal. According to Ozerov (2004), Liopiophila Duda is a synonym of Prochyliza Walker.

Immature stages live on carcasses and bones of a variety of dead animals (McAlpine, 1977). Smith (1986) also refers to cases in which this species was collected in animal carcasses (chicken, rabbit, fox), Kentner \& Streit (1990) collected it in rats, Bonduriansky \& Brooks (1999) in fish, rodents, moose carcasses and Carles-Tolrá (2001), mainly in dead chicken and animal fat. Only adults were collected in our experiment, in Coimbra.

MATERIAL EXAMINED: Coimbra - from 31.V.2004 to 3.VI.2004, 9 우 우, $30^{\top} \sigma^{7} ; 23$. VI.2004, $10^{\top} ;$ 24.VI.2004, $2 \sigma^{\top} \sigma^{\top}$.

Piophila casei (Linnaeus, 1758)

Piophila casei and Piophila megastigmata McAlpine, 1978 are the two species belonging to genus Piophila Fallén, 1810. Piophila casei is cos- mopolitan in distribution (McAlpine, 1977; Zuska, 1984). This is the first record of the species for mainland Portugal.

Larvae, also known as cheese skippers, infest meat, hides and bones of various animals, including fish. They often cause serious damage in the meat, leather and cheese industries (McAlpine, 1977). Many publications report the presence of this synanthropic species in animal carcasses (e.g. Wolff et al., 2001; Castillo-Miralbes, 2002; Watson \& Carlton, 2003; Sharanowski et al., 2008; Gomes et al., 2009) as well as in human corpses (e.g. Smith, 1986; Goff \& Flynn, 1991; Carvalho et al., 2000; Sukontason et al., 2001b; Wyss \& Cherix, 2006; Lefebvre \& Gaudry, 2009; Prado e Castro, unpublished data). We collected adults and larvae of this species.

The anterior spiracles of $P$. casei third-instar larvae present 10 papillae, arranged in two groups of 5, as described by Sukontason et al. (2001a). This clear bilobed arrangement that we also could observe with regular stereomicroscope, is not illustrated in Smith's (1986) textbook, which can lead to erroneous identification of larval stages of this species.

MATERIAL EXAMINED: Lisbon - 29.X.2006, $2 \sigma^{\top} \sigma^{\pi}$; 14.XI.2006, 1 ㅇ ; 18.XI.2006, 1 우 ; 27.IV.2007, 1 우 ; from 2.VII.2007 to 9.VII.2007, 25 우 우, $200^{7} \sigma^{\top}$.

\section{Prochyliza nigrimana (Meigen, 1826)}

Prochyliza nigrimana is one of the 8 species of the genus Prochyliza Walker, 1849 and seems to have accompanied man from the Holarctic to the Neotropical Region. The species is present in Eurasia, North and South America, Madeira, Azores and Canary islands (McAlpine, 1977; Zuska, 1984). New species record for continental Portugal.

Larvae have been reported to damage stored bones, having bred from decaying leaves (Zuska \& Lastovka, 1965). Few references associate this species with carcasses, as far as we are aware, only Carles-Tolrá (2001) reported it mainly from dead hedgehogs and chickens and Castillo-Miralbes (2002) from piglets. In our experiments, they also had a regular appearance, although only adults were collected. However one female was gravid in spring 2007, season in which this was the most abundant piophilid collected.

MATERIAL EXAMINED: Coimbra - from 1.VI.2004 to 4.VI.2004, 3 우 우, $20^{\top} \sigma^{7}$; 23.VI.2004, 1 우 ; Lisbon - from 
25.X.2006 to 1.XI.2006, 2 우 우, $4 \sigma^{x} \sigma^{x}$; from 21.IV.2007 to 29.IV.2007, 6 우 우, $180^{\circ} \sigma^{7}$; from 2.VII.2007 to 17.VII.2007, 2 우 우, $20^{7} \sigma^{7}$.

\section{Protopiophila latipes (Meigen, 1838)}

Protopiophila Duda, 1924 contains 10 species (Bonduriansky, 1995), primarily distributed in the Southern Hemisphere. Protopiophila latipes, the most widespread species, is present in the Holarctic Region and also in the Oriental and Australasian Regions (McAlpine, 1977; Zuska, 1984). New species record for Portugal.

Protopiophila latipes reproduces on corpses in advanced stages of decay, where females go to mate and oviposit (Bonduriansky, 1995). This species has been collected in carcasses of rats (Kentner \& Streit, 1990), rodents, turtles, fish, moose (Bonduriansky, 1995; Bonduriansky \& Brooks, 1999), chicken and hedgehogs, as well as in animal fat (Carles-Tolrá, 2001). In our case, only adults were collected, with 4 females gravid in spring 2004, season when it was the most abundant piophilid species.

MATERIAL EXAMINED: Coimbra - from 29.V.2004 to 27.VI.2004, 17 우 우, $220^{x} 0^{x}$; 7.VII.2004, $10^{\pi}$; 23.VIII.2004, 1 우 ; from 9.IX.2004 to 16.IX.2004, 5 우 우, $30^{x} 0^{x}$; Lisbon 30.X.2006, 1 \& ; 3.XI.2006, 1 ㅇ ; from 27.IV.2007 to 13.V.2007, $70^{7} \sigma^{x}$; from 6.VII.2007 to 21.VIII.2007, 1 우, $80^{x} \sigma^{x}$.

\section{Stearibia nigriceps (Meigen, 1826)}

Stearibia nigriceps is the only species of the genus Stearibia Lioy, 1864. It occurs in Eurasia, North and South America (McAlpine, 1977; Zuska, 1984).
McAlpine (1977) stated that immature stages probably lived on cadavers of various animals. This has been confirmed by several investigators that found this species in animal (e.g. Anderson \& VanLaerhoven, 1996; Bonduriansky \& Brooks, 1999; Carles-Tolrá, 2001; Castillo-Miralbes, 2002; Watson \& Carlton, 2003; Tabor et al., 2005; Matuszewski et al., 2008) and human cadavers (e.g. Smith, 1986; Wyss \& Cherix, 2006; Lefebvre \& Gaudry, 2009). We collected both adults and larvae. The species was particularly abundant in summer.

MATERIAL EXAMINED: Coimbra - from 1.VI.2004 to 13.VII.2004, 13 우 우, $130^{\pi} \sigma^{\pi}$; Lisbon - from 30.X.2006 to 12.XI.2006, $8 \sigma^{7} \sigma^{7}$; from 21.IV.2007 to 3.V.2007, 7 우 우, $90^{x} \sigma^{x}$; from 2.VII.2007 to 6.VIII.2007, 55 우 우, $570^{7} \sigma^{x}$.

The seasonal distribution of the different species collected is shown in Table 1.

In the spring 2004 experiment, in Coimbra, $L$. varipes was present, whereas the species was never collected in Lisbon. Piophila casei did not appear in Coimbra, but it was frequent in Lisbon. Since the type of bait and collecting technique was the same, these differences may be due to possible differences between habitats, even though both places are forested "islands" inside urbanized areas.

No species was active during winter, and summer was the season where a higher number of specimens were present in the carcass. Protopiophila latipes and P. nigrimana were the most abundant species in spring 2004 (Coimbra) and spring 2007 (Lisbon), respectively. Stearibia nigriceps was dominant, especially in the summer.

Piophilidae is clearly a saprophagous family, with a great proportion of species collected in

Table 1.- Total Piophilidae specimens (adults) collected in pig carcasses in Spring 2004 (Coimbra) and 2006-07 (Lisbon).

Table 1.- Número total de ejemplares adultos de Piophilidae colectados en cadáveres de cerdo en la primavera de 2004 (Coimbra) y en 2006-07 (Lisboa).

\begin{tabular}{lcccccc}
\hline & L. varipes & P. casei & P. nigrimana & P. latipes & S. nigriceps & Total \\
\hline Spring 2004 & 15 & & 6 & 49 & 26 & 96 \\
Autumn 2006 & & 4 & 6 & 2 & 8 & 20 \\
Winter 2007 & & 1 & 25 & 9 & 16 & 0 \\
Spring 2007 & & 45 & 4 & 9 & 112 & 51 \\
Summer 2007 & $\mathbf{1 5}$ & $\mathbf{5 0}$ & $\mathbf{4 1}$ & $\mathbf{6 9}$ & $\mathbf{1 6 2}$ & $\mathbf{3 3 7}$ \\
\hline \multicolumn{1}{c}{ Total } & & & & &
\end{tabular}


decomposing organic matter (Carles-Tolrá, 2001). The majority of works dealing with this Diptera family report $P$. casei and $S$. nigriceps as practically the only species associated with cadavers. It is interesting that for $P$. nigrimana and $P$. latipes, species with considerable abundance in our experiments, there are similar records in the Iberian Peninsula (Carles-Tolrá, 2001; Castillo-Miralbes, 2002). However we cannot be certain if the two species have bred on the cadavers.

All five species treated in this contribution have known and widespread distributions in Europe, therefore their presence in Portugal is not surprising. Despite this fact, the information presented greatly enlarges the knowledge on Piophilidae in Portugal, since the only contribution up to date was due to Hennig (1943). Besides the faunistic information, the data presented in this work has practical interest for forensic purposes. It provides information on the most common Piophilidae species in Portuguese territory, which certainly will be of major relevance in forensic cases.

\section{Acknowledgements}

We would like to thank Jardim Botânico da Universidade de Coimbra and Instituto Superior de Agronomia de Lisboa, for allowing the realization of fieldwork. C. Prado e Castro is supported by Fundação para a Ciência e Tecnologia through SFRH/BD/23066/2005 PhD grant.

\section{References}

Anderson, G. S. \& VanLaerhoven, S. L., 1996. Initial studies on insect succession on carrion in southwestern British Columbia. Journal of Forensic Sciences, 41: 617-625.

Bonduriansky, R., 1995. A new Nearctic species of Protopiophila Duda (Diptera: Piophilidae), with notes on its behaviour and comparison with $P$. latipes (Meigen). Canadian Entomologist, 127: 859-863.

Bonduriansky, R. \& Brooks, R. J., 1999. Reproductive allocation and reproductive ecology of seven species of Diptera. Ecological Entomology, 24: 389-395.

Carles-Tolrá, M., 2001. Datos taxonómicos y ecológicos de 304 especies de dípteros acalípteros (Diptera, Acalyptrata). Boletín de la Sociedad Entomológica Aragonesa, 28: 89-103.

Carles-Tolrá, M. \& Báez, M., 2002. Piophilidae. In: M. Carles-Tolrá (ed.). Catálogo de los Diptera de España, Portugal y Andorra (Insecta). Monografías SEA, Vol 8. Zaragoza: 182.
Carvalho, L. M. L., Thyssen, P. J., Linhares, A. X. \& Palhares, F. A. B., 2000. A checklist of arthropods associated with pig carrion and human corpses in southeastern Brazil. Memórias do Instituto Oswaldo Cruz, 95: 135-138.

Castillo-Miralbes, M., 2002. Estudio de la entomofauna asociada a cadáveres en el Alto Aragón (España). Monografias SEA, 6: 1-94.

Goff, M. L. \& Flynn, M. M., 1991. Determination of postmortem interval by arthropod succession: a casestudy from the Hawaiian-islands. Journal of Forensic Sciences, 36: 607-614.

Gomes, L., Gomes, G. \& Desuó, I., 2009. A preliminary study of insect fauna on pig carcasses located in sugarcane in winter in southeastern Brazil. Medical and Veterinary Entomology, 23: 155-159.

Gomez-Gómez, A., Díaz-Aranda, L. M. \& Michelsen, V., 2008. Rediscovery of Centrophlebomyia furcata (Fabricius, 1794) (Diptera: Piophilidae) in Europe. Studia dipterologica, 15(1/2): 231-237.

Hennig, W., 1943. Piophilidae. In: E. Lindner (ed.). Die Fliegen der palaearktischen Region, 5, Teil 40: 1-52.

Kentner, E. \& Streit, B., 1990. Temporal distribution and habitat preference of congeneric insect species found at rat carrion. Pedobiologia, 34: 347-359.

Lefebvre, F. \& Gaudry, E., 2009. Forensic Entomology: a new hypothesis for the chronological succession pattern of necrophagous insect on human corpses. Annales de la Société Entomologique de France, 45: 377-392.

Matuszewski, S., Bajerlein, D., Konwerski, S. \& Szpila, K., 2008. An initial study of insect succession and carrion decomposition in various forest habitats of Central Europe. Forensic Science International, 180: 61-69.

McAlpine, J. F., 1977. A revised classification of the Piophilidae, including 'Neottiophilidae' and 'Thyreophoridae' (Diptera: Schizophora). Memoirs of the Entomological Society of Canada, 103: 1-66.

Oosterbroek, P., 2006. The European Families of the Diptera. Identification, diagnosis, biology. KNNV Publishing. Utrecht. 205 pp.

Ozerov, A. L., 2000. Family Piophilidae. In: L. Papp \& B. Darvas (eds.). Contributions to a Manual of Palaearctic Diptera, Appendix. Science Herald. Budapest: 355-365.

Ozerov, A. L., 2004. [On classification of the family Piophilidae (Diptera).] Zoological Journal, 83(11): 1353-1360 (in russian).

Prado e Castro, C. B., 2005. Studies on Sarcosaprophagous Diptera (Insecta) in Central Portugal: Application to Forensic Entomology. MSc Thesis, Departamento de Zoologia, Faculdade de Ciências e Tecnologia da Universidade de Coimbra, Coimbra. 97 pp. 
Prado e Castro, C., Chichorro, D., Serrano, A. \& García, M. D., 2009. A modified version of Schoenly trap for collecting sarcosaprophagous arthropods. Detailed plans and construction. Anales de Biología, 31: 1-6.

Sharanowski, B. J., Walker, E. G. \& Anderson, G. S., 2008. Insect succession and decomposition patterns on shaded and sunlit carrion in Saskatchewan in three different seasons. Forensic Science International, 179: 219-240.

Simmons, P., 1927. The cheese skipper as a pest in cured meats. Department Bulletin, U.S. Department of Agriculture, 1453: 1-55.

Smith, K. G. V., 1986. A Manual of Forensic Entomology. The Trustees of the British Museum (Natural History). London. 205 pp.

Sukontason, K. L., Sukontason, K., Piangjai, S., Choochote, W., Vogtsberger, R. C. \& Olson, J. K., 2001a. Scanning electron microscopy of the thirdinstar Piophila casei (Diptera: Piophilidae), a fly species of forensic importance. Journal of Medical Entomology, 38: 756-759.

Sukontason, K., Sukontason, K., Vichairat, K., Piangjai, S., Lertthamnongtham, S., Vogtsberger, R. C. \& Olson, J. K., 2001b. The first documented forensic entomology case in Thailand. Journal of Medical Entomology, 38: 746-748.

Tabor, K. L., Fell, R. D. \& Brewster, C. C., 2005. Insect fauna visiting carrion in Southwest Virginia. Forensic Science International, 150: 73-80.

Watson, E. J. \& Carlton, C. E., 2003. Spring succession of necrophilous insects on wildlife carcasses in Louisiana. Journal of Medical Entomology, 40: 338347.
Wolff, M., Uribe, A., Ortiz, A. \& Duque, P., 2001. A preliminary study of forensic entomology in Medellin, Colombia. Forensic Science International, 120: 5359.

Wyss, C. \& Cherix, D., 2006. Traité d'Entomologie Forensique: Les insectes sur la scène de crime. Presses polytechniques et universitaires romandes. Lausanne. 317 pp.

Zuska, J., 1984. Family Piophilidae. In: Á. Soós \& L. Papp (eds.). Catalogue of Palaearctic Diptera, Micropezidae-Agromyzidae, Vol. 9. Akadémiai Kiadó. Budapest: 234-239.

Zuska, J. \& Lastovka, P., 1965. A review of the Czechoslovak species of the family Piophilidae with special references to their importance to food industry (Diptera, Acalyptrata). Acta Entomologica Bohemoslovaca, 62: 141-157. 